\title{
Work-family conflict and its antecedents among single mother employees
}

\begin{abstract}
Researchers have identified work-family conflict as one of the major stressors in the workplace leading to various negative outcomes, including impaired well-being. Although many studies have been conducted on the experience of work-family conflict on dual-earner couples, only a few were conducted on single parent employees. This study examines workfamily conflict among single mother employees and its antecedents including dispositional (locus of control and perfectionism), job (role overload, role conflict and job flexibility) and organizational (supervisor support) factors. Data were gathered from 159 Malaysian single mother employees using self-administered questionnaires. The findings of the study indicated that $66 \%$ of the single mother employees experienced moderate to high levels of work-family conflict. The factors that characterize employees disposition including locus of control and perfectionism, their job factors including role conflict and role overload, as well as their supervisors' support contributed significantly (51\%) to work-family conflict. The findings imply the need for measures to be taken by employees, human resource managers and organizations pertaining to the antecedent factors to help reduce the level of work-family conflict.
\end{abstract}

Keyword: Work-fFamily conflict, employee disposition, job factors, supervisor support, single mother employees 